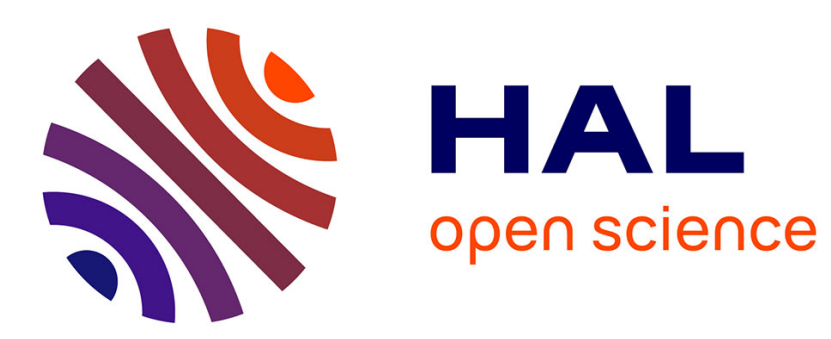

\title{
Small Molecular Donors for Organic Solar Cells Obtained by Simple and Clean Synthesis
}

Dora Demeter, Salma Mohamed, Andreea Diac, Ion Grosu, Jean Roncali

\section{To cite this version:}

Dora Demeter, Salma Mohamed, Andreea Diac, Ion Grosu, Jean Roncali. Small Molecular Donors for Organic Solar Cells Obtained by Simple and Clean Synthesis. ChemSusChem, 2014, 7 (4), pp.10461050. 10.1002/cssc.201301339 . hal-03344833

\section{HAL Id: hal-03344833 \\ https://univ-angers.hal.science/hal-03344833}

Submitted on 15 Sep 2021

HAL is a multi-disciplinary open access archive for the deposit and dissemination of scientific research documents, whether they are published or not. The documents may come from teaching and research institutions in France or abroad, or from public or private research centers.
L'archive ouverte pluridisciplinaire HAL, est destinée au dépôt et à la diffusion de documents scientifiques de niveau recherche, publiés ou non, émanant des établissements d'enseignement et de recherche français ou étrangers, des laboratoires publics ou privés. 


\title{
Small Molecular Donors for Organic Solar Cells Obtained by Simple and Clean Synthesis
}

\author{
Dora Demeter, ${ }^{[a]}$ Salma Mohamed ${ }^{[a]}$ Andreea Diac, ${ }^{[a, b]}$ Ion Grosu, ${ }^{[b]}$ and Jean Roncali*[a]
}

A small donor-acceptor molecule is synthesized in a two-step procedure involving reaction of $\mathrm{N}, \mathrm{N}$-diphenylhydrazine on 2,5diformylthiophene and Knoevenagel condensation. Results of UV/Vis absorption spectroscopy and cyclic voltammetry show that replacement of the phenyl ring bridge of a reference compound 2 by an azo group produces a slight red-shift of $\lambda_{\max }$ an enhancement of the molecular absorption coefficient, and a decrease of the energy level of the frontier orbitals. A preliminary evaluation of the potentialities of compound $\mathbf{1}$ as donor material in a basic bilayer planar heterojunction cell of $28 \mathrm{~mm}^{2}$ active area using $\mathrm{C}_{60}$ as acceptor gave a short-circuit current density of $6.32 \mathrm{mAcm}^{-2}$ and a power conversion efficiency of $2.07 \%$.

Organic photovoltaics (OPVs) are attracting increasing interest motivated by the technological opportunities offered by the lightness, plasticity, and flexibility of organic materials. ${ }^{[1-6]}$ However, besides scientific and technical interest, the considerable development of OPVs is mainly motivated by the expected drastic reductions of cost and environmental impact compared to the already established silicon solar cells.

In essence, designing an OPV cell involves the creation of a heterojunction by interfacing an electron donor material with an electron acceptor material. ${ }^{[1]}$ Soluble conjugated polymers constitute the main class of donor materials and high power conversion efficiencies (PCEs) of $8-9 \%$ have been reported for single-junction devices. ${ }^{[2]}$ However, the inherent polydispersity of polymers poses the problem of the reproducibility of the synthesis, purification, and, hence, composition and electronic properties of the active material. An alternative approach consists in replacement of the polymers by molecular donors. Molecular donors have been used in multilayer planar heterojunction (PHJ) cells fabricated by vacuum deposition for a long time, and the field is still very active. ${ }^{[3]}$ Soluble molecular donors introduced in 2005 in the fabrication of solution-processed bulk heterojunction (BHJ) solar cells ${ }^{[4]}$ have rapidly gained considerable interest and given rise to the synthesis of a huge number of new chromophores. ${ }^{[5]}$ The field has

[a] D. Demeter, S. Mohamed, A. Diac, J. Roncali

Group Linear Conjugated Systems

CNRS, Moltech-Anjou, University of Angers

2 Bd Lavoisier 49045 Angers (France)

E-mail: jeanroncali@gmail.com

[b] A. Diac, I. Grosu

Babes Bolyai University

Center of Supramolecular Organic and Organometallic Chemistry (CSOOMC)

Cluj-Napoca, 11 Arany Janos St., 400028 Cluj-Napoca (Romania) witnessed rapid progress and solution-processed $\mathrm{BHJ}$ cells with $P C E$ values comparable to those obtained with the best polymer-based devices have been recently reported by several groups. ${ }^{[6]}$ However, these high performances have been obtained with complex molecules of high molecular weight, prepared by multistep syntheses involving metal-catalyzed coupling reactions and with overall yields sometimes limited to a few percents.

In addition to problems of the cost of the synthesis, the presence of remnant traces of metals such as palladium or nickel can have deleterious effects on the performances of organic semi-conductors. ${ }^{[7]}$ Recently, several authors have discussed issues associated with the industrial development of OPV and emphasized the key role of the cost, scalability, and environmental impact of the synthesis of active material. ${ }^{[8]}$ In this context, our group has undertaken a project aimed at a drastic reduction of the size and complexity of molecular donors. ${ }^{[9,10]}$ This approach is expected to contribute to decrease the cost of active OPV materials by improving the overall yield and scalability of the synthesis and to limit its environmental impact by reducing the number of synthetic steps and avoid as much as possible, the use of metal-catalysts.

In recent years several groups have described efficient OPV cells fabricated by vacuum-deposition of small molecular donors. Thus, Würthner et al. have reported cells with $P C E$ of $6.10 \%$ based on merocyanines donors. ${ }^{[11]}$ Wong et al. have synthesized donor-acceptor molecules based on triphenylamine and fabricated solar cells with a maximum PCE of $6.80 \%$ using $\mathrm{C}_{70}$ as acceptor. ${ }^{[12]}$

We have recently described a cell of $4.0 \%$ PCE fabricated by co-evaporation of compound $\mathbf{2}$ (Scheme 1) and $\mathrm{C}_{60}$ as acceptor. ${ }^{[9-}$ ${ }^{a b},{ }^{13]}$ Furthermore, an even a smaller molecule such as compound 3 can still produce a short-circuit current density $\left(J_{s c}\right)$ of almost $7.0 \mathrm{mAcm}^{-2}$ and a PCE close to $2.0 \% .{ }^{[10 \mathrm{~b}]} \mathrm{How}-$ ever the light-harvesting properties of this molecule are limited $\left(\lambda_{\max }=473 \mathrm{~nm}, \lambda_{\text {onset }}=550 \mathrm{~nm}\right)$.

Grazulevicius et al. have widely developed hole-transporting materials synthesized by condensation of diarylhydrazines with various aldehydes. ${ }^{[14]}$ More recently this approach was used by Shen et al. for the synthesis of sensitizers for dyesensitized solar cells (DSSCs). ${ }^{[15]}$ As



Scheme 1. Chemical structure of the target donor 1 and reference compounds. 
a further step in the development of donor molecules for OPV combining simplicity, low molecular weight, and clean synthesis we report here the preparation of compound (1) with a diphenylhydrazone donor block and a preliminary evaluation of its potentialities as donor in basic bilayer PHJ cells.

The synthesis of compound 1 is depicted in Scheme 2. Shen et al. have synthesized sensitizers by a three-step synthesis involving reaction of $N^{\prime} N$-diphenylhydrazine with 2-thiophene carboxaldehyde followed by formylation of the free $\alpha$-position

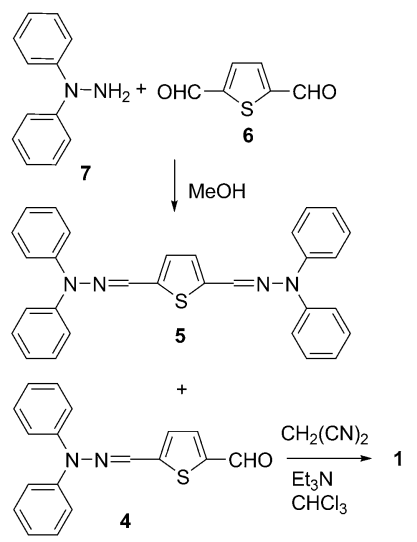

Scheme 2. Synthesis of the target compound 1 .

of thiophene of the resulting hydrazone and condensation with cyanoacrylic acid. ${ }^{[15]}$ In an attempt to simplify the synthesis by skipping the formylation step, we have directly reacted $N^{\prime} N$-diphenylhydrazine (7) with 2,5-thiophene dicarboxaldehyde (6). Reaction of 6 with one equivalent of 7 in methanol at low temperature gives as major product the bis-adduct $\mathbf{5}$ while the target monoaldehyde 4 was isolated in $12 \%$ yield. In a second series of experiments, one equivalent of 7 was reacted with 0.5 equivalent of dialdehyde 6 using a more dilute reaction medium. Under these conditions aldehyde 4 was isolated in $62 \%$ yield together with $21 \%$ of the bis-adduct 5 while $18 \%$ of the starting dialdehyde 6 were recovered. A Knoevenagel condensation of aldehyde $\mathbf{4}$ and malonodinitrile gave the target compound $\mathbf{1}$ in $70 \%$ yield (Scheme 2 ).

The UV/Vis absorption spectrum of compound 1 in methylene chloride shows an absorption maximum $\left(\lambda_{\max }\right)$ at $504 \mathrm{~nm}$ (Figure 1), which corresponds to a $31 \mathrm{~nm}$ bathochromic shift compared to compound 3 and a $3 \mathrm{~nm}$ red-shift compared to compound 2. Compound 1 shows a good solubility in chloroform $\left(25 \mathrm{mg} \mathrm{mL}^{-1}\right)$ and in chlorobenzene although the solubility is lower in this solvent $\left(12.5 \mathrm{mg} \mathrm{mL}^{-1}\right)$. The UV/Vis absorption spectra of thin-films cast on glass from solutions in these two solvents show in both cases a bathochromic shift of $\lambda_{\max }$ to ca. $525 \mathrm{~nm}$ and a broadening of the absorption band due to intermolecular interactions in the solid state.

A cyclic voltammogram (CV) of 1 recorded in $\mathrm{CH}_{2} \mathrm{Cl}_{2}$ with $\mathrm{Bu}_{4} \mathrm{NPF}_{6}$ as supporting electrolyte is shown in Figure 2. This $\mathrm{CV}$ exhibits a quasi-irreversible oxidation wave with an anodic peak potential $\left(E_{p a}\right)$ at $1.32 \mathrm{~V}$. The weak cathodic peak observed around $1.0 \mathrm{~V}$ in the reverse scan suggests the formation of
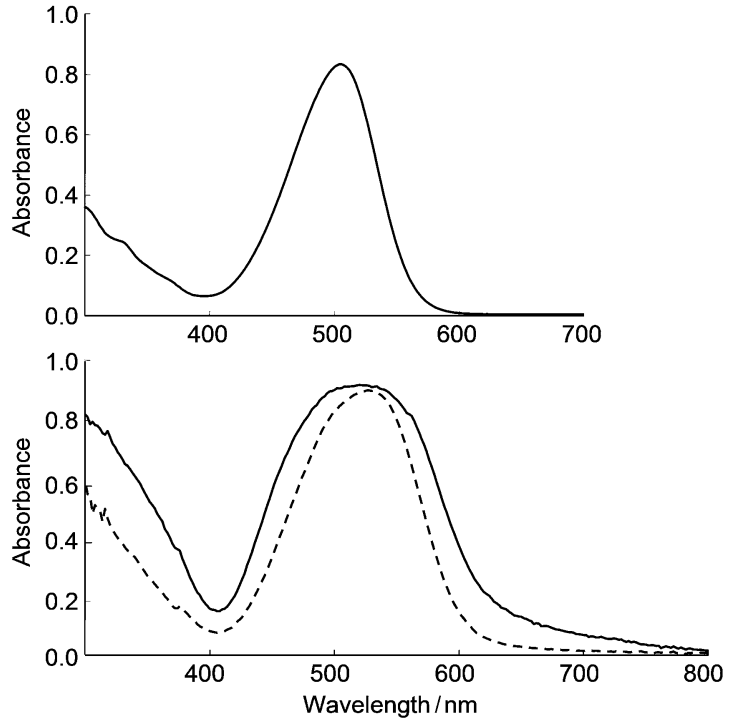

Figure 1. Top: UV/Vis absorption spectrum of compound 1 in methylene chloride. Bottom: normalized UV/Vis absorption spectra of thin films of compound 1 spun-cast on glass from chloroform solution (dashed line) and chlorobenzene solution (solid line).

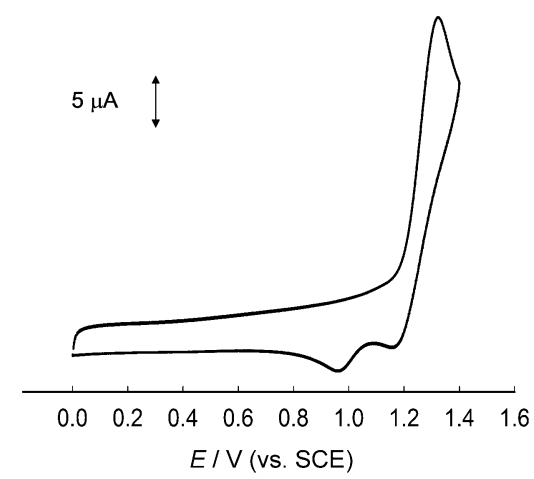

Figure 2. Cyclic voltammogram of compound 1 in $0.10 \mathrm{M} \mathrm{Bu} 4 \mathrm{NPF}_{6} / \mathrm{CH}_{2} \mathrm{C}_{12}, \mathrm{Pt}$ electrodes, scan rate $100 \mathrm{mV} \mathrm{s}^{-1}$.

a more extended conjugated system by coupling of the cation radical, as frequently observed in the electrochemistry of TPA derivatives. ${ }^{[16]}$ In the negative potential region (not shown), the $\mathrm{CV}$ shows an irreversible reduction wave peaking at $-0.91 \mathrm{~V}$ indicative of unstable anion radical. Comparison of the data for compound $\mathbf{1}$ to those for $\mathbf{2}$ and $\mathbf{3}$ shows that compound 1 presents the most red-shifted $\lambda_{\text {max }}$ the highest molecular absorption coefficient $(\varepsilon)$, and the lowest highest occupied molecular orbital (HOMO) and lowest unoccupied molecular orbital (LUMO) energy levels (Table 1). Considering the fact that the open-circuit voltage $\left(V_{\text {oc }}\right)$ of OPV cells depends on the difference between the LUMO of the acceptor and the HOMO of the donor, this deep HOMO level appears interesting. ${ }^{[17]}$ These results show that replacement of the phenyl bridge of compound 2 by an azo group produces interesting modifications of the electronic properties of the molecule regarding a possible use as donor in OPV cells. It is worth noting that these modifications are associated with a decrease of the molecular 


\begin{tabular}{|c|c|c|c|c|c|c|c|}
\hline Donor & $\begin{array}{l}\mathrm{MW} \\
{\left[\mathrm{g} \mathrm{mol}^{-1}\right]}\end{array}$ & $\begin{array}{l}\lambda_{\max } \\
{[\mathrm{nm}]}\end{array}$ & $\begin{array}{l}\varepsilon_{\max } \\
{\left[\mathrm{M}^{-1} \mathrm{~cm}^{-1}\right]}\end{array}$ & $\begin{array}{l}E_{\mathrm{pa}} \\
{[\mathrm{V}]}\end{array}$ & $\begin{array}{l}E_{\mathrm{pc}} \\
{[\mathrm{V}]}\end{array}$ & $\begin{array}{l}E_{\mathrm{HOMO}}{ }^{[\mathrm{a}]} \\
{[\mathrm{eV}]}\end{array}$ & $\begin{array}{l}E_{\text {LUMO }} \\
{[\mathrm{eV}]}\end{array}$ \\
\hline 1 & 354 & 504 & 39000 & 1.32 & -0.91 & -6.20 & -4.35 \\
\hline $2^{[\mathrm{b}]}$ & 403 & 501 & 33900 & 1.01 & -1.23 & -5.89 & -4.06 \\
\hline $\mathbf{3}^{[\mathrm{c}]}$ & 327 & 473 & 27000 & 1.20 & -1.17 & -6.08 & -4.12 \\
\hline
\end{tabular}

[a] Using an offset of $-4.99 \mathrm{eV}$ for SCE vs. the vacuum level. ${ }^{[18]}$ [b] From Ref. [9a]. [c] From Ref. [10b].

weight and a simplification of the synthesis with in particular the elimination of the Stille coupling involved in the synthesis of compound $2 .^{[9]}$

A preliminary evaluation of potentialities of compound 1 as donor for OPV has been carried out on bilayer PHJ cells fabricated by spin-casting a ca. $20 \mathrm{~nm}$ thick film of 1 from a chloroform solution onto indium tin oxide (ITO) substrates precoated with poly(3,4-ethylenedioxythiophene):poly(styrenesulfonate) (PEDOT:PSS). The substrates were then introduced into a vacuum chamber, a $30 \mathrm{~nm}$ thick layer of $C_{60}$ or $C_{70}$ fullerene acceptor was deposited by thermal evaporation under a pressure of $2 \times 10^{-6} \mathrm{mbar}$, and the devices were completed by deposition of a $100 \mathrm{~nm}$ layer of aluminum. Although the solubility of compound 1 could allow the fabrication of solution-processed $\mathrm{BHJ}$ cells, no attempt at that direction was made at this stage. In fact $\mathrm{BHJ}$ cells generally require tedious optimization work whereas simple $\mathrm{PHJ}$ cells, although less efficient, are more suitable for a first evaluation of new materials as they give more reproducible and more reliable results.

As shown in Table 2, as-fabricated cells show short-circuit current densities $\left(J_{\mathrm{sc}}\right)$ in the range of 2.50 to $3.50 \mathrm{~mA} \mathrm{~cm}^{-2}$ and $P C E$ of 0.60 to $0.80 \%$. Devices containing $C_{70}$ as acceptor give slightly better $J_{s c}$ and PCE values but lower fill factors (FF). Application of a $10 \mathrm{~min}$ thermal treatment at $100^{\circ} \mathrm{C}$ strongly improves the photovoltaic characteristics with in particular a large increase of $J_{s c}$ to values exceeding $6.00 \mathrm{~mA} \mathrm{~cm}^{-2}$. After annealing, the best results are obtained with $C_{60}$. Although we

\begin{tabular}{|c|c|c|c|c|c|c|}
\hline Cell & Acceptor & $\begin{array}{l}\text { Ann. temp } \\
{\left[{ }^{\circ} \mathrm{C}\right]}\end{array}$ & $\begin{array}{l}J_{\mathrm{sc}} \\
{\left[\mathrm{mAcm}^{-2}\right]}\end{array}$ & $\begin{array}{l}V_{\text {oc }} \\
{[V]}\end{array}$ & $\begin{array}{l}F F \\
{[\%]}\end{array}$ & $\begin{array}{l}P C E \\
{[\%]}\end{array}$ \\
\hline 1 & $\mathrm{C}_{60}$ & ambient & 2.48 & 0.84 & 27.4 & 0.63 \\
\hline 2 & $\mathrm{C}_{60}$ & ambient & 2.05 & 0.89 & 28.1 & 0.57 \\
\hline 3 & $C_{70}$ & ambient & 3.17 & 0.86 & 23.9 & 0.72 \\
\hline 4 & $C_{70}$ & ambient & 3.46 & 0.88 & 25.5 & 0.85 \\
\hline 1 & $\mathrm{C}_{60}$ & 100 & 6.32 & 0.79 & 37.4 & 2.07 \\
\hline 2 & $\mathrm{C}_{60}$ & 100 & 5.72 & 0.82 & 35.3 & 1.83 \\
\hline 3 & $C_{70}$ & 100 & 4.64 & 0.87 & 29.3 & 1.31 \\
\hline 4 & $C_{70}$ & 100 & 4.16 & 0.89 & 29.1 & 1.19 \\
\hline 1 & $\mathrm{C}_{60}$ & 110 & 6.40 & 0.75 & 33.1 & 1.76 \\
\hline 2 & $\mathrm{C}_{60}$ & 110 & 6.50 & 0.64 & 37.3 & 1.72 \\
\hline 3 & $C_{70}$ & 110 & 4.73 & 0.77 & 27.9 & 1.13 \\
\hline 4 & $C_{70}$ & 110 & 5.27 & 0.77 & 27.4 & 1.23 \\
\hline
\end{tabular}

have no explanation for this phenomenon it can be hypothesized that the thermally-induced rearrangement of the active donor/acceptor (D/A) interfacial zone is different for the two acceptors. Application of higher annealing temperature $\left(110^{\circ} \mathrm{C}\right)$ produces a small further increase of $J_{s c}$ but begins to deteriorate $V_{\text {oc }}$ and $F F$ values. Figure 3 shows the $J-V$ curves for the best device of the series, which gave a $J_{s c}$ of $6.32 \mathrm{mAcm}^{-2}$, a $V_{\text {oc }}$ of $0.79 \mathrm{~V}$, and a PCE of $2.07 \%$.
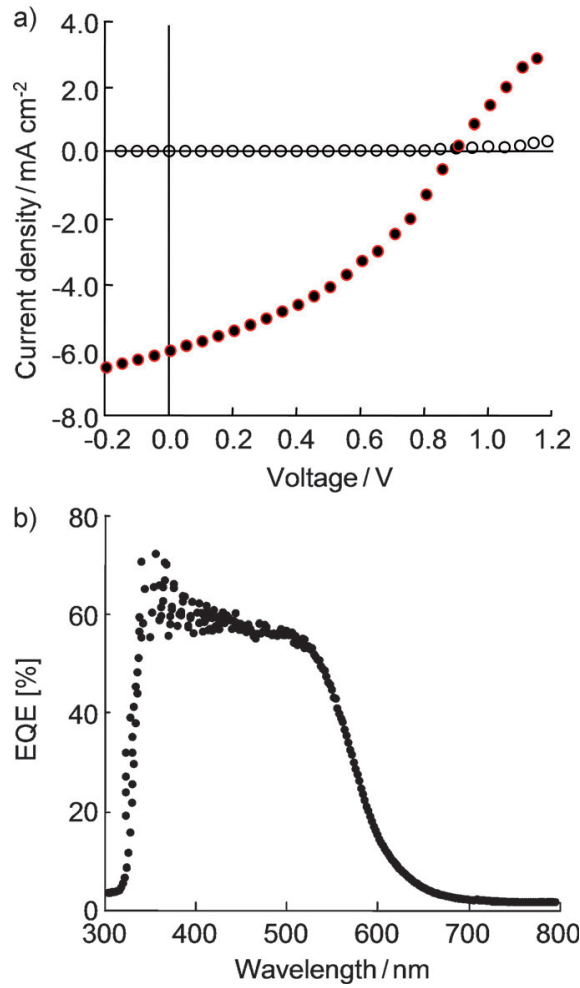

Figure 3. a) Current density-voltage curves for a bilayer solar cell (ITO/PEDOT:PSS $/ 1 / C_{60}$ /aluminium. In the dark (open circles) and under simulated solar light with incident power light of $90 \mathrm{~mW} \mathrm{~cm}^{-2}$ (black circles). b) External quantum efficiency spectra of the bilayer cells $1 / C_{60}$.

Figure 3 (bottom) shows the external quantum efficiency $(E Q E)$ action spectrum of the best device under monochromatic irradiation. The spectrum shows a broad maximum of ca. $55-60 \%$ in the $400-600 \mathrm{~nm}$ region with an onset of photocurrent at ca. $620 \mathrm{~nm}$. Although these results are encouraging they also underline the need for improving the light-harvesting properties of the donor by further structural modification.

When evaluated in the above conditions, reference compound 2 gives a PCE of $2.50 \%$. In a recently published paper, a thorough optimization of the device architecture has allowed to increase this value to $4.00 \%$ for cells based on co-evaporated bulk heterojunction of donor and $C_{60}$ layer. ${ }^{[13]}$ This result suggests that there is still room for improvement in the case of donor 1.

To summarize, a soluble push-pull molecule has been synthesized using two condensation reactions with water as byproduct. Comparison of the electronic properties to those of a reference compound shows that replacement of thiophene 
by an azo bridge leads at the same time to a decrease of molecular weight and to improved optical properties and energy levels a priori favorable for photovoltaic conversion. Preliminary tests with simple bilayer solar cells show that performances comparable to those reported for much larger molecules evaluated in optimized devices of smaller active area can be obtained with a small molecule obtained by simple and clean chemistry.

Work aiming at the extension of this synthetic approach with in particular optimization of the selectivity of the reaction of diphenylhydrazine with dialdehydes, the design of molecules with improved light-harvesting properties, and further evaluation in $\mathrm{BHJ}$ cells is now underway and will be reported in future publications

\section{Experimental Section}

\section{General}

NMR spectra were recorded with a Bruker AVANCE III $300\left({ }^{1} \mathrm{H}\right.$, $300 \mathrm{MHz}$ and $\left.{ }^{13} \mathrm{C}, 75 \mathrm{MHz}\right)$ or Bruker AVANCE DRX $500\left({ }^{1} \mathrm{H}, 500 \mathrm{MHz}\right.$ and ${ }^{13} \mathrm{C}, 125 \mathrm{MHz}$ ). Chemical shifts are given in ppm relative to TMS. Infrared spectra were recorded on a Bruker spectrometer Vertex 70 and UV/Vis spectra with a Perkin-Elmer Lambda 19 or 950 spectrometer. Melting points are uncorrected. Matrix Assisted Laser Desorption/lonization was performed on MALDI-TOF MS BIFLEX III Bruker Daltonics spectrometer using dithranol as matrix. Cyclic voltammetry was performed in dichloromethane solutions purchased from SDS (HPLC grade). Tetrabutylammonium hexafluorophosphate $(0.10 \mathrm{M}$ as supporting electrolyte) was purchased from Acros and used without purification. Solutions were deaerated by nitrogen bubbling prior to each experiment. Experiments were carried out in a one-compartment cell equipped with platinum electrodes and saturated calomel reference electrode (SCE) with a Biologic SP-150 potentiostat with positive feedback compensation.

\section{Synthesis}

5-((2,2-diphenylhydrazono)methyl)thiophene-2-carbaldehyde (4). A solution of thiophene-2,5-dicarbaldehyde (6) $(1.27 \mathrm{~g}, 9.06 \mathrm{mmol})$ in $50 \mathrm{~mL}$ of dry THF is added dropwise to a mixture of $\mathrm{N}, \mathrm{N}$-diphenylhydrazine hydrochloride (7) $(1.0 \mathrm{~g}, 4.53 \mathrm{mmol})$ and sodium acetate $(1.40 \mathrm{~g}, 18.12 \mathrm{mmol})$ in $15 \mathrm{~mL}$ of dry methanol under argon atmosphere at room temperature. The reaction mixture is stirred overnight at room temperature and then diluted with methylene chloride, washed with water and brine. After removal of the solvent the residue is chromatographed on silica gel using methylene chloride as eluent to afford a yellow powder $(0.85 \mathrm{~g}, 62 \%)$. ${ }^{1} \mathrm{H}$ NMR $\left(300 \mathrm{MHz}, \mathrm{CDCl}_{3}\right): \delta=9.85(\mathrm{~s}, 1 \mathrm{H}), 7.61(\mathrm{~d}, 1 \mathrm{H}, J=3.9 \mathrm{~Hz}), 7.47-7.42$ $(\mathrm{m}, 5 \mathrm{H}) 7.27-,7.18(\mathrm{~m}, 6 \mathrm{H}) ,6.19 \mathrm{ppm}(\mathrm{d}, 1 \mathrm{H}, J=3.9 \mathrm{~Hz})$. MALDITOF: 306.2

(E)-2-((5-((2,2-diphenylhydrazono)methyl)thiophen-2-yl)methylene)malononitrile (1) Aldehyde $4150 \mathrm{mg}(0.45 \mathrm{mmol})$ was dissolved in $15 \mathrm{~mL}$ of chloroform, malononitrile $(60 \mathrm{mg}, 0.9 \mathrm{mmol}, 2$ equiv) and one drop of triethylamine were added. The mixture was refluxed for two hours. The solvent was evaporated and the product was purified by column chromatography on silica gel (eluting with dichloromethane), yielding a yellow powder $(0.12 \mathrm{~g}, 0.316 \mathrm{mmol}$, $70 \%)$. ${ }^{1} \mathrm{H}$ NMR $\left(300 \mathrm{MHz}, \mathrm{CDCl}_{3}\right): \delta=7.70(\mathrm{~s}, 1 \mathrm{H}), 7.62(\mathrm{~d}, 1 \mathrm{H}, J=$ $3.9 \mathrm{~Hz}), 7.48-7.43\left(\mathrm{~m}, 4 \mathrm{H}_{1}\right) 7.29-7.27(\mathrm{~d}, 2 \mathrm{H}, J=7.5 \mathrm{~Hz}) 7.20-7.17$ $(\mathrm{m}, 5 \mathrm{H}), 7.01 \mathrm{ppm}(\mathrm{d}, 1 \mathrm{H}, J=3.9 \mathrm{~Hz}) \cdot{ }^{13} \mathrm{C}$ NMR $\left(75 \mathrm{MHz}, \mathrm{CDCl}_{3}\right): \delta=$
153.8, 150.0, 142.3, 139.1, 133.8, 130.0, 127.3, 126.4, 125.8, 122.5, 122.4, 114.5, 113.5, 75.7 ppm. MS MALDI-TOF: 354.2.

\section{Device fabrication and testing}

Indium-tin oxide coated glass slides of $24 \mathrm{~mm} \times 25 \mathrm{~mm} \times 1.1 \mathrm{~mm}$ dimensions with a surface resistance of $10 \Omega / \square$ were purchased from Kintec company. Part of the ITO layer was etched away with $37 \% \mathrm{HCl}$. The ITO electrodes were then cleaned in ultrasonic bath (successively Deconex (from VWR international $\mathrm{GmbH}$ ), distilled water $\left(15.3 \mathrm{M} \Omega \mathrm{cm}^{-1}\right)$, acetone, ethanol and distilled water again for $10 \mathrm{~min}$ each and dried in an oven at $100^{\circ} \mathrm{C}$. The dried electrodes were then modified by a spun-cast layer of PEDOT:PSS (Clevios P VP. Al 4083 (HC-Starck) filtered through a $0.45 \mu \mathrm{m}$ membrane just prior use). Spin-casting was achieved at $5000 \mathrm{rpm}(\mathrm{r}=10 \mathrm{~s}, \mathrm{t}=$ $60 \mathrm{~s}$ ), and the electrode was then dried at $130^{\circ} \mathrm{C}$ for $15 \mathrm{~min}$. Films of donor materials (ca $20 \mathrm{nmnm}$ ) were spun-cast in atmospheric conditions from choloform solutions containing $4 \mathrm{mg}$ donor $/ \mathrm{mL}$. After film deposition the devices were introduced in an argon glovebox (200B, MBraun) equiped with a vacuum chamber and a $25 \mathrm{~nm}$ film of Fullerene $C_{60}(99+\%)$ (MER Corporation) and a $100 \mathrm{~nm}$ thick aluminium electrode were thermally evaporated on top of the donor film under a pressure of $2 \times 10^{-6} \mathrm{mbar}$ through a mask defining two cells of $6.0 \mathrm{~mm}$ diameter $\left(0.28 \mathrm{~cm}^{2}\right)$ on each ITO electrode.

The $J$ vs $V$ curves of the devices were recorded in the dark and under illumination using a Keithley 236 source-measure unit and a home-made acquisition program. The light source was an AM1.5 Solar Constant 575 PV simulator (Steuernagel Lichttechnik, equipped with a metal halogen lamp). The light intensity was measured by a broad-band power meter (13PEM001, Melles Griot). The devices were illuminated through the ITO electrode side. The efficiency values reported here are not corrected for the possible spectral mismatch of the solar simulator. External quantum efficiency (EQE) was measured using a halogen lamp (Osram) with an Action Spectra Pro 150 monochromator, a lock-in amplifier (PerkinElmer 7225) and a S2281 photodiode (Hamamatsu).

Keywords: condensations · donor-acceptor · energy
conversion $\cdot$ photovoltaics $\cdot$ solar cells

[1] C. W. Tang, Appl. Phys. Lett. 1986, 48, 183.

[2] a) Z. He, C. Zhong, S. Su, M. Xu, H. Wu, Y. Cao, Nat. Photonics 2012, 6, 591 ; b) C. Cabanetos, A. El Labban, J. A. Barteld, J. D. Douglas, W. M. Mateker, J. M. J. Fréchet, M. D. McGhee, P. M. Beaujuge, J. Am. Chem. Soc. 2013, 135, 4656.

[3] a) G. A. Chamberlain, Solar Cells 1983, 8, 47; b) D. Wöhrle, D. Meissner, Adv. Mater. 1991, 3, 129; c) P. Peumans, A. Yakimov, S. R. Forrest, J. Appl. Phys. 2003, 93, 3693-3723; d) A. Mishra, P. Bäuerle, Angew. Chem. Int. Ed. 2012, 51, 2020; Angew. Chem. 2012, 124, 2060.

[4] J. Roncali, P. Frère, P. Blanchard, R. de Bettignies, M. Turbiez, S. Roquet, P. Leriche, Y. Nicolas, Thin Solid Films 2006, 511, 567.

[5] Reviews: a) M. T. Lloyd, J. M. Anthony, G. C. Malliaras, Mater. Today 2007, 10, 34; b) J. Roncali, Acc. Chem. Res. 2009, 42, 1719; c) B. Walker, C. Kim, T.-Q. Nguyen, Chem. Mater. 2011, 23, 470; d) Y. Lin, Y. Li, X. Zhan, Chem. Soc. Rev. 2012, 41, 4245; e) Y. Chen, X. Wan, G. Long, Acc. Chem. Res. 2013, 46, 2645.

[6] a) Y. Sun, G. C. Welch, W. L. Leong, C. J. Takacs, G. C. Bazan, A. J. Heeger, Nat. Mater. 2011, 11, 44; b) J. Zhou, Y. Zuo, X. Wan, G. Long, Q. Zhang, W. Ni, Y. Liu, Z. Li, G. He, C. Li, B. Kan, M. Li, Y. Chen, J. Am. Chem. Soc. 2013, 135, 8484; c) S. Shen, P. Jiang, C. He, J. Zhang, P. Shen, Y. Zhang, Y. Yi, Z. Zhang, Z. Li, Y. Li, Chem. Mater. 2013, 25, 2274.

[7] H. E. Katz, Z. Bao, S. L. Gilat, Acc. Chem. Res. 2001, 34, 359. 
[8] a) D. J. Burke, D. J. Lipomi, Energy Environ. Sci. 2013, 6, 2053; b) T. P. Osedach, T. L. Andrew, V. Bulovic, Energy Environ. Sci. 2013, 6, 711; c) F. Krebs, M. Jørgensen, Solar Energy Mater. Solar Cells 2013, 119, 73.

[9] a) A. Leliège, C.-H. Le Régent, M. Allain, P. Blanchard, J. Roncali, Chem. Commun. 2012, 48, 8907; b) A. Leliège, D. Demeter, V. Jeux, T. Rousseau, P. Leriche, P. Blanchard, J. Roncali, Chem. Eur. J. 2013, 19, 9948; c) D. Demeter, V. Jeux, P. Leriche, P. Blanchard, Y. Olivier, J. Cornil, R. Po, J. Roncali, Adv. Funct. Mater. 2013, 23, 4854.

[10] a) D. Demeter, T. Rousseau, J. Roncali, RSC Adv. 2013, 3, 704; b) V. Jeux D. Demeter, P. Leriche, J. Roncali, RSC Adv. 2013, 3, 5811.

[11] a) V. Steinmann, N. M. Kronenberg, M. R. Lenze, S. M. Graf, D. Hertel, K. Meerholz, H. Bürckstümmer, E. V. Tulyakova, F. Würthner, Adv. Energy Mater. 2011, 1, 888; b) H. Bürckstümmer, E. V. Tulyakova, M. Deppish M. R. Lenze, N. M. Kronenberg, M. Gsänger, M. Stolte, K. Meerholz, F. Würthner, Angew. Chem. Int. Ed. 2011, 50, 11628; Angew. Chem. 2011, 123, 11832.

[12] Y.-H. Chen, L.-Y. Lin, C.-W. Lu, F. Lin, Z.-Y. Huang, H.-W. Lin, P.-H. Wang, Y.H. Liu, K.-T. Wong, J. Wen, D. J. Miller, S. B. Darling, J. Am. Chem. Soc 2012, 134, 13616
[13] J. W. Choi, C. H. Kim, J. Pison, A. Oyedele, H. Derbal-Habak, D. Tondelier A. Leliège, E. Kirchner, P. Blanchard, J. Roncali, B. Geffroy, RSC Adv. 2014, 4, 5236.

[14] R. Lygaitis, V. Getautis, J. V. Grazulevicius, Chem. Soc. Rev. 2008, 37, 770.

[15] a) P. Shen, X. Liu, S. Jiang, L. Wang, L. Yi, D. Ye, B. Zhao, S. Tan, Dyes Pigm. 2012, 92, 1042; b) P. Shen, X. Liu, S. Jiang, L. Huang, L. Yi, D. B. Zhao, S. Tan, Org. Electron. 2011, 12, 1992.

[16] R. N. Adams, Acc. Chem. Res. 1969, 2, 175.

[17] C. J. Brabec, A. Cravino, D. Meissner, N. S. Sariciftici, T. Fromhertz, M. Rispens, L. Sanchez, J. C. Hummelen, Adv. Funct. Mater. 2001, 11, 374.

[18] D. Baran, A. Balan, S. Celebi, B. Meana Esteban, H. Neugebauer, N. S. Sariciftci, L. Toppare, Chem. Mater. 2010, 22, 2978.

Received: December 12, 2013

Revised: January 18, 2014

Published online on $\mathbf{\square}$ II, 0000 


\section{COMMUNICATIONS}

D. Demeter, S. Mohamed, A. Diac,

I. Grosu, J. Roncali*

Small Molecular Donors for Organic Solar Cells Obtained by Simple and Clean Synthesis

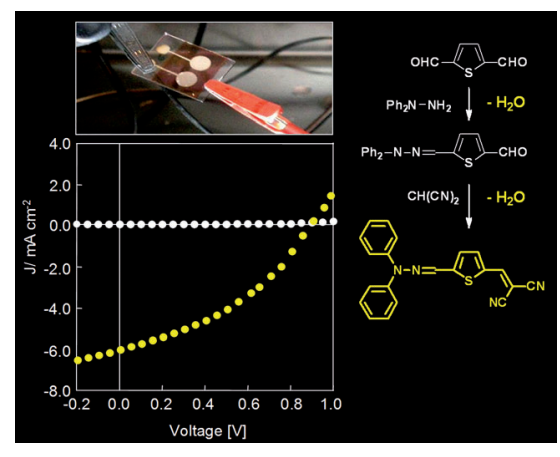

Keep it simple: A simple donor-acceptor molecule is synthesized from 2,5thiophene dialdehyde using two condensation reactions with water as sole by-product. A $30 \mathrm{~mm}^{2}$ simple bilayer solar cell fabricated with a spun-cast film of donor and vacuum-deposited $C_{60}$ shows a power conversion efficiency $>2.0 \%$ under simulated solar light. 